\title{
Pengenalan Pembelajaran Matematika oleh Orang Tua Anak Usia Dini di Masa Pandemi
}

\author{
Berta Laili Khasanah $^{1 凶}$, Dimyati ${ }^{2}$ \\ Pendidikan Anak Usia Dini, Universitas Negeri Yogyakarta, Indonesia(1) \\ Pendidikan Keolahragaan, Universitas Negeri Yogyakarta, Indonesia(2) \\ DOI: $10.31004 /$ obsesi.v6i2.1016
}

\begin{abstract}
Abstrak
Dampak virus Corona (Covid-19) menjadikan sekolah tidak dibuka dan melakukan belajar dari rumah. Selama belajar dari rumah, keterlibatan orang tua menjadi sangat penting terutama dalam mengenalkan konsep matematika pada anak usia dini. Tujuan dari penelitian ini adalah untuk mengetahui upaya pengenalan pembelajaran matematika oleh orang tua anak usia dini di masa pandemi. Desain penelitian ini adalah kajian literatur. Pengumpulan data dilakukan melalui berbagai sumber baik buku, skripsi, thesis, disertasi, dan publikasi artikel jurnal. Berdasarkan hasil kajian literatur pengenalan pembelajaran matematika oleh orang tua sebaiknya dengan metode bermain dan menggunakan media benda hidup atau mati yang berada di sekolah, di rumah, di jalan maupun di sekitar lingkungan anak. Berbagai tips kegiatan belajar matematika dari rumah seperti menghitung benda konkret, mengulang dengan bernyanyi sambil berhitung, berhitung menyentuh benda, bermain peran, dan tebak angka. Dengan begitu, kemampuan matematika berupa menghitung, mengelompokkan, mengurutkan, membandingkan, dan konsep geometri dapat terstimulasi dengan baik dan anak tidak bosan.
\end{abstract}

Kata Kunci: matematika; pandemi; orang tua anak usia dini.

\begin{abstract}
The impact of the Corona virus (Covid-19) has prevented schools from opening and learning from home. During learning from home, parental involvement is very important, especially in introducing math concepts to early childhood. The purpose of this study was to determine the introduction of mathematics learning for parents of early childhood during the pandemic. The design of this research is literature review. Data collection was carried out through various sources including books, theses, theses, dissertations, and journal article publications. Based on the results of a literature review, the introduction of mathematics learning by parents should use the playing method and using the media of living or inanimate objects at school, at home, on the street or around the child's environment. Various tips for learning math activities from home such as counting concrete objects, repeating by singing while counting, counting touching objects, role playing, and guessing numbers. That way, math skills in the form of calculating, grouping, sorting, comparing, and geometric concepts can be stimulated well and the child will not be bored.
\end{abstract}

Keywords: math; pandemic; parents early childhood.

Copyright (c) 2021 Berta Laili Khasanah, Dimyati

$\triangle$ Corresponding author :

Email Address : bertalaili.2019@student.uny.ac.id (Jl, Samirono Baru No.46 Yogyakarta 55281)

Received 31 December 2020, Accepted 24 January 2021, Published 4 June 2021 


\section{PENDAHULUAN}

Penyebaran virus Corona (Covid-19) telah meluas ke seluruh belahan dunia dengan cepat, menimbulkan perubahan pola aktivitas saat ini pada seluruh sektor kehidupan manusia. Pada Kementerian Pendidikan dan Kebudayaan (Kemendikbud) Indonesia telah memberlakukan kebijakan Belajar dari Rumah dengan sistem pembelajaran jarak jauh melalui motode sekolah online (Wardhani \& Krisnani, 2020) sudah selama 10 bulan sejak Februari 2020. Hal ini sesuai dengan Pemerintah yang telah menetapkan kebijakan belajar dari rumah atau biasa disingkat BDR melalui Surat Edaran Mendikbud Nomor 36962/MPK.A/HK/ 2020 yang berisikan bahwa pembelajaran harus dilakukan secara daring supaya Corona Virus Desease (Covid-19) dapat dicegah penyebarannya (Karnawati \& Mardiharto, 2020).

Pada proses lembaga pendidikan menjadi tidak bisa melaksanakan proses pembelajaran seperti biasa, sehingga meliburkan seluruh aktivitas pendidikan. Kebijakan ini juga diambil oleh Indonesia. Oleh karena itu, saat ini orang tua menjadi pengambil peran pengganti baik sebagai orang tua ataupun menjadi guru. Meskipun orang tua merupakan sekolah pertama bagi anaknya dari kandungan bahkan sekarang orang tua baik ayah maupun ibu sebagai garda terdepan yang mengawal anak - anaknya tetap belajar dirumah masing masing. Mereka sangat berperan penting dalam tumbuh kembang anaknya, dalam seluruh perkembangan.

Penelitian terkini menunjukkan bahwa, pengaruh keterlibatan orang tua terhadap keyakinan dan perilaku anak dapat menjadi sebuah kontribusi penting yang mengarah pada pencapaian yang positif (Kim, 2015). Ketika orang tua dapat berpartisipasi dalam sekolah mereka menjadi role model ketika menyatukan budaya rumah dan sekolah. Orang tua membimbing anak untuk dapat berperilaku positif dan harus memiliki prestasi akademik yang unggul. Orang tua berpersepsi bahwa, mengembangkan number sense awal memainkan peran penting dalam meletakkan landasan bagi prestasi akademik matematika di masa depan anak-anak dan akan berguna untuk membangun latar belakang yang kuat untuk belajar matematika tingkat lanjut (Yilmaz, 2017). Sehingga orang tua selalu mengarahkan dan menekan anak untuk dapat mencapai tujuan yang diinginkan orang tua yaitu dapat menghitung dengan lancar. Akibatnya anak dapat mengalami gangguan psikologis ketika belum siap menghadapi tekanan yang seharusnya anak usia dini masih menikmati masa bermain.

Bagi sebagian orangtua mendampingi anak saat bermain atau belajar bukanlah pekerjaan yang ringan, apalagi bila harus mengaitkannya dengan tujuan dan manfaat dari setiap kegiatan bermain anak. Demikian halnya dengan mengembangkan kemampuan matematika pada anak. Menurut Musrikah (2017) pengenalan matematika di TK bukanlah tindakan yang dapat sembarangan, sehingga harus mengacu pada standar yang berlaku, penyampaian materi setidaknya mempertimbangkan dua hal yaitu konsep yang benar dan cara yang benar. Cara yang benar yaitu dilakukan tepat sesuai umur dan dilakukan menggunakan metode bermain. Sebab jika tidak sesuai konsep di awal pengenalannya akan mengakibatkan miskonsep dan berlanjut pada tingkatan selanjutnya. Sedangkan penyajian matematika yang tidak memperhatikan level berpikir, akan mengakibatkan kelelahan, kejenuhan dan phobia pada matematika. Kesalahan yang terjadi terkadang anak sering dituntut untuk menghafalkan angka, menghitung jumlah, menuliskan berbagai lambang dan bahasa matematika, tanpa memperhatikan level berpikirnya dan prinsip dasarnya (Lestari KW, 2011). Sehingga orang tua seharusnya mengupayakan dalam mengenalkan matematika dilakukan dengan bermain agar dapat mewujudkan pembelajaran matematika yang ideal.

Kendala lain yang dihadapi orangtua seperti kurang siapnya orangtua dalam memandu anak dalam belajar di suasana stay at home dan work from home ini (Purwanto et al., 2017). Terkadang para orangtua juga harus meyelesaikan baik pekerjaan kantor dan pekerjaan rumah dilakukan dalam waktu yang bersamaan, sehingga menyebabkan orangtua menjadi stres dengan banyaknya beban tugas yang harus dilakukan bersamaan tersebut (Purwanto et al., 2017). Kesempatan untuk belajar di dalam rumah juga terbatas, mengingat kemampuan 
orang tua dalam memberikan Dukungan pendidikan kepada anak-anak mereka akan dibentuk oleh tingkat pencapaian pendidikan mereka sendiri, tingkat keaksaraan umum, dan komitmen lainnya terbatas (Obiakor et al., 2020). Mengingat hubungan yang signifikan antara pencapaian pendidikan dan tingkat pendapatan, dan korelasi antara tingkat pendapatan orang tua dan pilihan sekolah berpengaruh.

Selain itu, jika orang tua anak memiliki perangkat elektronik dan gadget ada masalah lain yaitu kepedulian orang tua. Selama masa belajar di rumah faktor keterlibatan orang tua dalam e-learning di PAUD mutlak diperlukan. Faktor keterlibatan orangtua seperti kondisi sosial ekonomi orangtua, latar belakang pendidikan orangtua, bahasa, dan kemampuan komunikasi guru/sekolah (Irma et al., 2019). Namun keterlibatan orangtua masih rendah karena ketidaksesuaian program PAUD dengan kebutuhan anak dan orangtua, kekurangan pembiayaan, kekurangan SDM, ketidakberhasilan keberlanjutan program anak di rumah, serta perkembangan anak tidak akan maksimal (Oktavianingsih, 2019). Maka pendidik perlu mengetahui kondisi orang tua wali baik sosial ekonomi, latar belakang pendidikan dan hubungan komunikasi antara pendidik dan orang tua wali agar dapat bekerjasama dalam mendampingi anak belajar dirumah menjadi lebih berpartisipasi.

Hasil kajian literatur menunjukkan bahwa, pembelajaran matematika bagi anak usia dini dimasa pandemi Covid-19 harus menyenangkan dan objek pembelajarannya sederhana, konkret dan dekat dengan anak (Amalina, 2020). Hal ini sesuai dengan (Kemdikbud, 2015) bahwa, dalam melakukan kegiatan atau belajar anak dapat optimal jika dilakukan melalui bermain, didukung oleh fasilitator, dan menggunakan media serta sumber media yang mudah ditemukan. Sesuai dengan hakikat anak usia dini bermain sambil belajar, belajar seraya bermain sehingga anak tidak sadar bahwa permainan yang mereka lakukan atau hal sederhana yang disampaikan orang tua kepada anak adalah pembelajaran matematika.

Permainan dapat mengubah persepsi anak bahwa matematika itu sulit dan anak menjadi lebih rileks ketika bermain sambil belajar. Namun, di sisi lain matematika dianggap penting karena perannya sebagai prediktoryang kuat bagi anak untuk memasuki sekolah formal dibanding keterampilan emosi dan sosial (Siregar \& Restati, 2017) bahkan anak-anak dapat meningkatkan kreatifitas matematika dari pengetahuan informal yang diperoleh dan dapat meningkatkan kemampuan memecahkan masalah. Kemampuan orang tua mengenalkan pengalaman matematika untuk anak dalam kehidupan sehari-hari melalui percakapan dengan orang tua atau guru mereka yang telah diprediksi secara positif memiliki interaksi matematis yang lebih kuat dengan mereka, yang pada gilirannya berkontribusi pada mereka perkembangan kognitif (Bae \& Kim, 2020). Meskipun dirumah interaksi matematis orang tua didefinisikan sebagai interaksi alami, verbal dan non-verbal antara orang tua dan anak-anaknya tentang konsep matematika dan pemecahan masalah matematika dalam kehidupan sehari-hari (Kim, 2015).

Beberapa penelitian sebelumnya telah menargetkan para orang tua muda anak-anak, dan satu penelitian Korea menunjukkan bahwa, program pendidikan orang tua berdampak positif berpengaruh pada peningkatan efektivitas pengajaran matematika orang tua (Hur, 2012). Namun bertolak belakang dengan (Amalina, 2020) bahwa, salah satu pembelajaran yang merupakan dasar keilmuan namun menjadi sulit untuk diajarkan dan menjadi momok bagi banyak kalangan orangtua anak adalah mengajarkan matematika sejak dini, aktivitas di lapangan lebih cenderung kepada aktivitas calistung yang lebih dominan.

Selain itu, banyak orang tua memiliki ketakutan terhadap matematika atau biasa dikenal kecemasan matematika. Hasil penelitiaan menemukan bahwa sebanyak 45\% mempersepsikan matematika cukup sulit, dan sebanyak $80 \%$ mengatakan matematika merupakan pelajaran yang penting, serta $85 \%$ siswa mengatakan bahwa belajar matematika melalui game adalah menyenangkan (Siregar \& Restati, 2017). Saat kecemasan matematika anak meningkat, kinerja matematikanya cenderung meningkat menurun. Bahkan, beberapa penelitian menunjukkan bahwa emosi negatif seseorang memiliki tanggapan terhadap matematika dan kecemasan matematika seseorang yang berhubungan dengan matematika 
prestasi orang lain, sikap, dan kecemasan. Kecemasan itu sendiri muncul karena situasi belajar yang menekan. Siswa yang lebih cemas akan berusaha semakin keras, tapi pemahaman mereka akan semakin memburuk, sehingga semakin membuatnya cemas (Ramadan, 2019).

Di negara Amerika pernah meremehkan matematika dan akibatnya mengalami penurunan prestasi di tahun 2012 yang mulanya di posisi 12 menjadi di posisi bawah (Bae \& Kim, 2020; Kerkhof, 2017). Matematika memiliki penerapan dunia nyata serta hampir setiap profesi menggunakan beberapa bentuk matematika, dan matematika diperlukan untuk melakukan banyak tugas harian yang berbeda, seperti memberi tahu waktu, membaca odometer, menghitung perubahan, dan membuat keputusan dalam kehidupan kerja seseorang (Bae \& Kim, 2020).

Matematika adalah suatu bentuk pembelajaran yang menggunakan logika (Ramadan, 2019). Matematika adalah ilmu eksak untuk kehidupan sehari-hari yang sangat berguna. Menyadari pentingnya matematika, kita harus mempelajarinya dari tingkat awal ke tingkat yang lebih mendalam lagi. Untuk itu, penguasaan matematikanya sejak dasar sangat berpengaruh dan memiliki manfaat di kekhidupan selanjutnya.

Manfaaat yang dapat diambil ketika anak-anak dikenalkan matematika sejak dini oleh orang tua di masa pandemi yaitu, membelajarkan anak konsep matematika yang benar dengan cara yang menarik dan menyenangkan, menghindari ketakutan terhadap matematika sejak awal, membantu anak belajar matematika secara alami melalui bermain, menstimulasi aspek perkembangan kognitif anak untuk belajar memecahkan masalah, berpikir logis, kritis, dan kreatif; mengenal konsep matematika secara matang sebagai dasar untuk kemampuan membaca anak (misalnya: kemampuan untuk mengenal bentuk, memahami posisi kanan kiri), membangun aspek sosial emosional, anak belajar untuk bekerja sama dengan teman atau orang dewasa, percaya diri, mandiri, sabar serta mampu belajar menaati aturan main (Kemdikbud, 2020).

Sehingga penting dalam rumusan masalah untuk mengetahui bagaimana upaya yang dilakukan orang tua dalam mengenalkan matematika pada anak usia dini dimasa pandemi. Meskipun selama pandemi covid 19, orang tua memiliki pekerjaan lain dan pengenalan matematika di awal masa kanak-kanak harus tetap diajarkan secara utuh tanpa terkecuali meski harus dilakukan secara menyeluruh (Sa \& Kurniawati, 2020). Oleh karena itu, anak sejak dini perlu dikenalkan atau bahkan dibelajarkan tentang matematika, bergelut, dan merasakan matematika sebagai bagian kehidupannya. Namun yang harus diketahui bahwa orang tua perlu menggunakan interaksi yang menantang, menarik sesuai pekembangan, dekat dengan anak, menggunakan media dan sumber media benda konkret ataupun sesuai kebutuhan, bukan karena paksaan.

\section{METODOLOGI}

Penulisan artikel ini menggunakan metode berupa review literatur. Metode ini mencari hasil berbagai sumber untuk mejawab pertanyaan pembelajaran matematika oleh orang tua anak usia dini di masa pandemi dari hasil penelitian-penelitian sebelumnya. Pengumpulan data dilakukan melalui berbagai sumber baik buku, penelitian skripsi, thesis, disertasi, dan publikasi artikel jurnal untuk mendukung kajian tentang pengenalan matematika oleh orang tua untuk anak usia dini. Penelitian ini menggunakan metode review literatur bertujuan untuk mengumpulkan hasil-hasil penelitian, agar lebih mengetahui dan memperdalam serta keluasan pengetahuan mengenai pembelajaran matematika oleh orang tua anak usia dini di masa pandemi.

Tahapan dalam membuat review literatur pembelajaran matematika oleh orang tua anak usia dini, yaitu: memilih topik yang berkaitan dengan pembelajaran matematika, memilih artikel yang cocok/relevan dengan pembelajaran matematika oleh orang tua anak usia dini di masa pandemi, selanjutnya membaca dan mencari kata kunci untuk di jadikan bahan artikel agar bisa di analisis serta di sintesis untuk dijadikan kesimpulan, setelah di 
analisis kemudian di organisasi disusun dan digabungkan agar sejalan dengan pemikiran dengan penulis. Hal ini sejalan dengan langkah-langkah review literatur (Ramdhani, Amin \& Ramdhani, 2014).

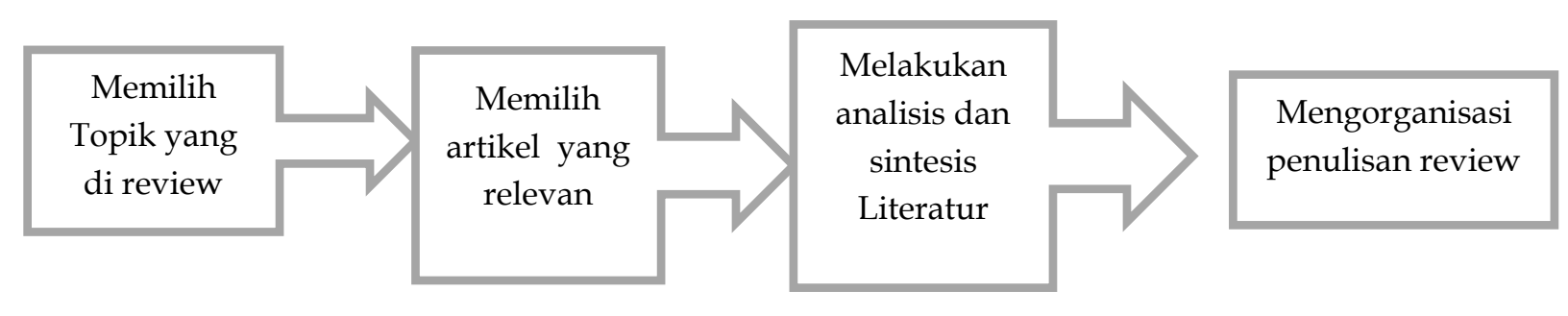

Gambar 1. Tahapan Review Literatur

\section{HASIL DAN PEMBAHASAN}

Pembelajaran jarak jauh yang biasa disebut daring telah mengubah pola pembelajaran yang awalnya tatap muka menjadi tidak tatap muka (virtual) akibat adanya Pandemi Covid19. Salah satu kendala dalam sistem pembelajaran daring ini seperti adanya kurangnya dan terbatasnya pengetahuan akan penggunaan teknologi. Terutama orang tua pada kondisi seperti sekarang dituntut untuk membimbing anaknya dalam pembelajaran berbasis daring. Bagi orang tua anak yang gagap teknologi akan menjadi suatu tantangan tersendiri dalam membimbing anaknya, sedangkan Bagi orang tua anak yang terbiasa menggunakan teknologi mungkin tidak menjadi masalah atau bahkan justru menjadi suatu kemudahan dalam berkomunikasi dan efisien tanpa terikat waktu.

Menurut Sa'ida \& Kurniawati (2020) pengenalan matematika dimulai sejak dini masa kanak-kanak melalui pembelajaran online dapat dilakukan dengan pembelajaran melalui media permainan edukatif, mainan anak-anak, media sosial, dan konferensi video. Pengenalan matematika bagi anak oleh orang tua tentunya harus dilakukan dengan metode bermain dan sesuai dengan tahap perkembangan usia anak. Penting untuk diketahui jika belajar matematika itu terjadi secara alami ketika anak bermain. Ada tiga tahapan penguasaan konsep matematika bagi anak melalui permainan seperti a) Penguasaan konsep tentang sesuatu melalui benda-benda dan peristiwa yang konkret, b) Proses berpikir kongkrit pada masa transisi dengan cara mengenalkan benda kongkrit dengan bentuk lambangnya. c) Visualisasi konsep lambang, seperti lambang 8 untuk mencontohkan konsep bilangan delapan, kuning untuk menggambarkan konsep warna, besar dan kecil untuk menggambarkan konsep ruang (Wardhani, 2017).

Selain menggunakan metode bermain, berdasarkan hasil penelitian, belajar online menggunakan WA Group sangat efektif dalam pandemi COVID-19. Terbukti dari hasil presentase $48.9 \%$ yang paling tinggi dibandingkan media sosial yang lainnya seperti zoom, google class room, e-learning (Wargadinata et al., 2020). Sehingga, adanya berbagai sumber media yang digunakan dalam mengerjakan pembelajaran setiap harinya anak perlu adanya pembiasaan baru agar tetap nyaman dan cocok dalam mengerjakan kegiatan bersama dengan orang tua.

Selama pandemi orang tua menjadi memiliki peran penuh untuk dapat menjadi guru, dan orang tua. Dilihat dari sudut pandang orang tua sebagai guru yang selalu memiliki peran selama 24 jam, seperti dalam penentuan kurikulum, silabus, materi dan pembelajaran anak (Eminita \& Astriyani, 2018). Selain itu, orang tua berperan aktif dalam melatih kemampuan life skill pada anak (A'yun et al., 2015) . Sehingga, sekarang orang tua tidak hanya melatih kemampuan life skill dan pemahaman agama, namun penting juga untuk mengenalkan pembelajaran matematika sejak dini. Dalam mengenalkan pembelajaran matematika dapat bersumber dari apa saja dan media apa sasa, baik yang ada sekolah, di rumah, di jalan maupun di sekitar lingkungan anak. 
Selama pembelajaran dirumah, media yang digunakan anak hanya disekitar lingkungan anak dan menggunakan peran orang tua untuk mendampingi anak. Sehingga orang tua perlu mengambil peran sebagai guru dalam rumah mereka, meskipun mengandalkan bimbingan dari sekolah. Sebagian besar media pembelajaran akan menggunakan barang-barang di dekat lingkungan rumah anak dan orang tua memiliki tanggung jawab dalam menyiapkan media-media seperti menggunakan peralatan dapur, alatalat kebersihan, dan barang-barang lainya sehingga orang tua dapat menentukan dan mengalokasikan penggunaan di antara barang-barang tersebut sesuai kebutuhan (Obiakor et al., 2020). Sehingga di waktu pandemi sekarang orang tua memiliki peran dalam mendukung belajar dari rumah.

Selain itu, matematika bukan hanya disiplin menghitung angka namun juga kemampuan berpikir matematis dan memecahkan masalah (Kim, 2015). Matematika itu bersifat kaku, tidak dapat berkembang dan hanya memiliki satu jawaban yang benar untuk setiap permasalahan. Hal ini salah satunya mungkin disebabkan oleh, kajian matematika suatu pembelajaran yang materinya bersifat abstrak (Murdiani, 2018). Ciri Keabstrakan matematika beserta ciri lainnya yang tidak sederhana, menyebabkan matematika tidak mudah untuk dipelajari, dan pada akhirnya banyak siswa yang kurang tertarik terhadap matematika. Pada sebagian orang menganggap bahwa matematika adalah ilmu yang sulit dipelajari, membuat orang stress, kepala pusing, dan membosankan. Namun penguasaan konsep matematika anak usia dini seperti menemukan, menguji serta menerapkan konsep matematika secara alami hampir setiap hari dalam hal yang mereka lakukan.

Berdasarkan hasil penelitian, kegiatan belajar matematika secara sederhana terjadi dalam kehidupan sehari-hari anak, seperti saat orang tua menghitung bersama anaknya yang berumur empat tahun untuk mengetahui berapa balok yang digunakan untuk membangun jembatan. Kedua, seperti saat anak dan orang tua sedang mendiskusikan cangkir siapa yang lebih besar atau ember mana yang memuat pasir atau air lebih banyak (Diana, 2017). Beberapa kegiatan tersebut telah mengenalkan tentang konsep bilangan dan pengukuran, serta dapat mengembangkan keahlian untuk menyelesaikan masalah berdasarkan konsep bilangan dan pengukuran dengan pemecahan masalah saat bekerja melalui metode bermain.

Pendapat Diana (2017), juga diperkuat oleh (Sa \& Kurniawati, 2020) bahwa, matematika mampu merambah ke segala bidang kehidupan. Oleh karena itu, matematika merupakan ilmu yang penting untuk dikenalkan pada anak usia dini, karena dalam kehidupan sehari-hari kita sering menggunakan kemampuan matematika. Selama pandemi covid 19, pengenalan matematika di awal masa kanak-kanak harus tetap diajarkan secara utuh tanpa terkecuali, meski harus dilakukan secara menyeluruh pembelajaran online (Sa \& Kurniawati, 2020). Terlihat dari kegiatan seperti melihat waktu, menghitung benda, menghitung uang, memasak, mengenali bentuk, mengelompokkan benda dan sebagainya. Contoh ini merupakan sebagian kecil dari penggunaan matematika dalam kehidupan seharihari. Selain itu, dengan membaca anak-anak dapat menghitung buku, menyanyikan lagu berhitung, dan bermain menghitung permainan, anak-anak bersenang-senang dengan angka dan memberi mereka dasar untuk sukses dalam matematika (Giganti, 2001). Sehingga meskipun menggunakan kegiatan-kegiatan sederhana seperti yang telah disebutkan anakanak dapat belajar mengenal konsep matematika secara sederhana.

Jika di lihat lebih jauh, keterampilan yang dibutuhkan oleh anak untuk memahami konsep matematika, yaitu: menyusun pola atau gambar, penyortiran atau pengelompokkan, mengurutkan dan menyambungkan, memulai konsep angka dan pemecahan masalah (Diana, 2017). Hal ini di dukung Kemdikbud (2020) bahwa, konsep matematika permulaan yang perlu dikenalkan kepada anak usia dini di antaranya adalah mencocokkan, mengelompokkan, seriasi, geometri, pola, bilangan, grafik, dan pengukuran.

Berikut akan diuraikan tentang upaya orang tua dalam mengenalkan pembelajaran matematika untuk memahami konsep matematika dimasa pandemi, yaitu: menyusun pola 
atau gambar, penyortiran atau pengelompokkan, bilangan, geometri, mengurutkan dan menyambungkan, grafik, dan pengukuran.

\section{Menyusun pola atau gambar}

Tujuan mengenalkan pola dan hubungan pada anak usia 3-6 tahun adalah untuk mengenalkan dan menganalisa pola-pola sederhana, menjiplak, membuat, dan membuat perkiraan tentang kemungkinan dari kelanjutan pola. Kegiatan yang bisa dilakukan orang tua untuk mengembangkan pola dan hubungan pada anak seperti, pola yang paling umum adalah pola abab: merah, kuning, merah, kuning. Pola lainnya termasuk pola AABB : merah, merah, kuning, kuning ataupun pola $\mathrm{ABCABC}$ : piring, sendok, gelas, piring sendok gelas. Anak-anak dapat membuat pola menggunakan warna, bentuk, ukuran atau karakteristik lain yang diulang beberapa kali (Kemdikbud, 2020). Mengenalkan pembelajaran pola juga dapat melalui pembuatan pola suara seperti : "ayo tepuk tangan dengan keras, keras, pelan, keras, pelan" hal ini agar anak dapat memahami berbagai pola yang ada di dalam pola suara (Novikasari, 2016). Hal ini juga diperkuat Mirawati (2017) bahwa kegiatan mengenalkan pola juga bisa menggunaan media music video nursery rhym. Berupa anak menirukan gerakan dari video "Head And Shoulder". Sehingga anak mampu menyebutkan ke lanjutan pola sederhana berdasar-kan warna, bentuk atau objek .

\section{Penyortiran atau pengelompokan}

Kegiatan ini dapat berupa menghitung dan mengelompokkan benda-benda di rumah satukan pisau, garpu, serta sendok dari laci dapur lalu minta anak anda mengelompokkannya berdasarkan jenisnya. Minta ia menghitung berapa jumlah pada tiap kelompoknya. Lakukan hal yang sama pada kaos kaki dengan mengelompokkannya berdasarkan warna dan ukuran. Begitu juga dengan koleksi boneka mainannya, kelompokkan boneka binatang berdasarkan ukuran besar dan kecil. Atau kelompokkan semua boneka beruang menjadi satu. Minta anak membantu orang tua melipat dan merapikan pakaian. Kemudian tanyakan padanya, "Ada berapa jumlah kaos kakinya, Kak?" Atau dengan bertanya, "Berapa jumlah semua baju, Kak?" Lalu minta ia membaginya dalam beberapa kelompok (Ismawati, 2020).

\section{Bilangan}

Pengenalan angka pada anak usia dini diawali dengan pemahaman konsep bilangan, transisi dan lambang bilangan. Pada tahap pemahaman konsep, anak dikenalkan konsep bilangan menggunakan benda konkret, contohnya dikenalkan konsep bilangan satu dengan memegang satu buah sendok. Selanjutnya, setelah anak memahami konsep bilangan anak akan berada pada tahap pra operasional. Kegiatan yang dapat dilakukan misalnya, anak ditunjukkan angka 2 kemudian mampu mengambil dua sendok atau anak ditunjukkan angka 2 kemudian menunjuk gambar dua sendok (Kemdikbud, 2020). Bisa juga dengan kegiatan mengajak anak bernyanyi lagu satu satu, balonku, dan lainnya yang mengandung angka sambil bergerak mengikuti irama (Safira dan Itadah, 2020). Kegiatan lain, meminta anak untuk memasukan bola plastik ke keranjang, kemudian ajaklah anak untuk menghitung bersamasama jumlah bola yang ada di keranjang (Giganti, 2001). Selain itu, kemampuan matematika dengan permainan jam pintar adalah solusi ketika anak belum mengenal konsep matematika, maka anak dapat akan melihat langsung angka yang tertera pada jam pintar. Sebaliknya dibalik angka ada konsep angka sesuai dengan lambang bilangan yang ada pada jam tersebut, anak bisa menghitung dengan sendirinya anak kenal konsep matematika (Fauziddin, 2015). Penggunaan benda konkret ini dapat menambah pemahaman lebih cepat diserap anak, karena pada masa anak usia dini masih berada dimasa golen ege. Sehingga orang tua dapat memanfaatkan masa golden ege tersebut agar tumbuh secara optimal. 


\section{Geometri}

Geometri merupakan konsep matematika yang berkaitan dengan bentuk-bentuk seperti lingkaran, persegi, segitiga, dan persegi panjang dan hubungan spasial di mana letak benda-benda itu pemahaman ruang/ posisi (Kemdikbud, 2020). Pemahaman tersebut diantaranya konsep atas bawah di atas, tinggi rendah, di depan di belakang, dan di dalam di luar. Kegiatan yang bisa dilakukan orangtua untuk mengembangkan hubungan geometri dan ruang pada anak seperti bermain busa. Kegiatan ini dengan mengajak anak bermain meniup busa sabun menggunakan sedotan plastik yang ditekukan pada bagian ujungnya sehingga membentuk lingkaran lalu diikatkan ke batang sedotan. Ajak anak mengamati bahwa bentuk gelembung-gelembung sabun yang ditiup anak seperti bentuk lingkaran (Lestari KW, 2011). Selain itu, konsep geometri ketika dijalan orang tua dapat mengenalkan rambu lalu lintas untuk mengenali bentuk lingkaran dalam geometri(Bozick et al., 2017).

\section{Mengurutkan}

Seriasi adalah kemampuan yang lebih tinggi dari membandingkan. Seriasi merupakan kemampuan menempatkan benda-benda dalam satu urutan misalnya, dari urutan yang kecil ke yang lebih besar atau sebaliknya. ketika dirumah kegiatan yang dilakukan di halaman bisa mengurutkan ketinggian tanaman.Kegiatan yang dapat dilakukan bersama dengan orang tua Ajak anak ke halaman, bersama anak temukan letak pot-pot berisi tanaman. Ajak anak untuk mengamati persamaan dan perbedaan pot-pot berisi tanaman yang sudah dikumpulkan. Ajak anak untuk mengurutkan pot-pot berisi tanaman berdasarkan ketinggiannya. Apabila sudah selesai, foto hasil kegiatan mengurutkan pot-pot berisi tanaman (Kemdikbud, 2020).

\section{Grafik}

Membuat grafik merupakan cara untuk menampilkan informasi/data yang diperoleh agar terlihat jelas jumlahnya dan mudah membacanya. kegiatan yang bisa dilakukan orangtua untuk mengembangkan pengumpulan, pengaturan dan tampilan data pada anak yaitu : a) Mencatat binatang peliharaan anak. Tiga anak memiliki ikan. Enam anak memiliki kucing. Dua anak memiliki kelinci. Tujuh anak tidak memilikihewan peliharaan. Kemudian menunjukkan informasi tersebut pada tabel atau dapat dengan grafik batang (Novikasari, 2016), b) Membuat grafik sederhana dengan menggunakan baskom yang dimiliki mama di rumah atau bisa menggunakan baju untuk membuat grafik (Kemdikbud, 2020).

\section{Pengukuran}

Pengenalan awal pengukuran pada anak, orang tua perlu mengenalkan konsep lebih panjang, lebih pendek, lebih ringan, lebih berat, lebih cepat, dan lebih lambat. Tahap berikutnya, anak diajak menggunakan alat ukur tidak standar, seperti langkah kaki, jengkal, dan hasta. Pada tahap lebih tinggi lagi, anak diajak menggunakan alat ukur standar seperti: jam dinding, jam tangan, penggaris, termometer, dan meteran (Kemdikbud, 2020).

Perlu di ingat bahwa, tips bagi orang tua agar pengenalan pembelajaran matematika bersama anak berhasil dengan baik, menurut (Wardhani, 2017) yaitu: pertama lakukan pengulangan hal ini dimaksudkan untuk pemuatan sehingga, konsep lebih tertanam di otak anak. Kedua, lingkungan yang kondusif agar berkembang secara optimal. Ketiga, belajar apapun akan sangat efektif jika pembelajarannya menyenangkan dan menggunakan media yang beragam.

Senada dengan Wardhani (2017); Giganti (2015) juga memiliki tips untuk orang tua dalam mengenalkan matematika saat belajar dari rumah pada anak usia dini, yaitu seringlah menghitung dan temukan hal-hal yang dapat dihitung setiap hari, di mana saja, dan apa saja dalam segala hal. Kedua, menghitung benda nyata seperti kue, koin, mainan, dan lain-lain. Anak-anak akan menemukan bahwa, berhitung lebih dari sekedar mengulang nyanyian saat mereka menghitung benda nyata. Ketiga, menghitung dengan menyentuh benda ataupun menghitung dengan jari, karena jari adalah alat matematika terbaik anak-anak punya. 
Belajar bisa dari mana saja dan bersumber dari siapa saja. Menurut Giganti (2015), belajar dari rumah untuk mengenalkan matematika sejak dini dapat berbagai sudut area yang berada di rumah. Jika di area rumah anak dapat belajar matematika dari menghitung balokbalok saat dia membangun menara, menyortir mainan berdasarkan ukuran, jenis, atau warna. Menyusun boneka, mobil, atau balok dari yang terbesar hingga terkecil. Mainan tebakantebakan seperti "Apa yang saya pikirkan?" Dengan mendeskripsikan ukuran dan bentuk mainan dan dapat bermain peran "toko" khayalan dengan mainan dan uang mainan dengan orang tua atau keluarga.

Jika di area dapur orang tua dapat mengenalkan matematika untuk konsep geometri dengan cara kegiatan mencari bentuk dua dimensi yang sudah dikenal berbentuk lingkaran, persegi, segitiga,dan lainnya seperti, piring bundar atau serbet persegi. Kegiatan seriasi atau mengurutkan kaleng makanan atau toples berdasarkan ukuran atau jenisnya. Pengenalan konsep matematika dalam mengelompokkan dapat menggunakan kegiatan memilah peralatan makan dari mesin pencuci piring dimasukkan ke laci, memilih dan menghitung piring, perkakas, cangkir. Konsep membilang dapat melakukan berbagi sepiring kue secara merata sehingga, setiap anggota keluarga mendapat bagian yang sama dan memutuskan apa yang harus dilakukan jika masih ada yang tersisa. Konsep ukuran dapat melakukan tebak angka berupa pertanyaan ke pada anak seberapa banyak gelas susu dalam satu karton susu penuh. Membantu anak menggandakan resep, atau memotong satu menjadi dua (Giganti, 2001).

Berdasarkan penelitian dalam beberapa tahun terakhir dipercaya bahwa, proses matematis perlu dilakukan dan ditekankan dalam konteks kehidupan sehari-hari yang intuitif dan informal, reorganisasi, kuantifikasi, abstraksi, generalisasi, representasi, dll, (Kim, 2015). Dikarenakan, semakin tinggi intensitas interaksi maka, semakin efektif orang tua dapat meningkatkan kemampuan matematika dan mengembangkan sikap matematika yang positif. Sehingga berdasarkan berbagai kajian literatur yang telah dikumpulkan dari berbagai sumber ilmiah dapat menjadi gambaran bagi orang tua untuk melakukan pengenalan pembelajaran matematika di masa pandemi.

\section{SIMPULAN}

Pengenalan matematika oleh orang tua kepada anak sebaiknya menggunakan metode bermain dan sesuai tahap perkembangan anak. Pengenalan matematika dapat bersumber dari benda hidup dan mati serta berbagai media seperti yang berada di sekolah, rumah, di jalan maupun di sekitar lingkungan. Berbagai tips pengenalan matematika dari rumah dapat dengan cara: menghitung benda konkret, mengulang dengan bernyanyi sambil berhitung, berhitung menyentuh benda, bermain peran, dan bermain tebak angka. Maka dari itu, kemampuan pengenalan matematika berupa menghitung, mengelompokkan, mengurutkan, membandingkan, dan konsep geometri dapat terstimulasi dengan baik. Orang tua dan anak juga semakin antusias dalam bermain matematika.

\section{UCAPAN TERIMA KASIH}

Terima kasih kepada Allah Subhanahu Wata'ala, orang tua, penulis-penulis artikel yang mendukung dalam artikel ini serta pembimbing yang telah memberi dukungan dan bimbingan kepada peneliti sehingga telah selesai artikel ini. Semoga pihak-pihak yang telah membantu dapat mendapat pahala yang mengalir.

\section{DAFTAR PUSTAKA}

A'yun, Q., Prihartanti, N., \& Chusniatun. (2015). Peran Orangtua dalam Pendidikan Anak Usia Dini (Studi Kasus pada Keluarga Muslim Pelaksana Homeschooling). Jurnal Indigenous, 13(2), 33-40.

http://journals.ums.ac.id/index.php/indigenous/article/view/2601 
Amalina, A. (2020). Pembelajaran Matematika Anak Usia Dini di Masa Pandemi COVID-19 Tahun 2020. Jurnal Obsesi: Jurnal Pendidikan Anak Usia Dini, 5(1), 538. https://doi.org/10.31004/obsesi.v5i1.592

Bae, J., \& Kim, J. (2020). A home connection program to promote mathematical interactions of parents: Effects on parents' mathematical interactions, parent-teacher cooperative relationship, and three-year-olds' mathematical ability. Asia-Pacific Journal of Research in Early Childhood Education, 14(3), 113-138. https://doi.org/10.17206/apjrece.2020.14.3.113

Bozick, R., Owings, J. A., Frye, D., Baroody, A. J., Burchinal, M., Carver, S. M., Jordan, N. C., McDowell, J., Lortie-Forgues, H., Tian, J., Siegler, R. S., Powell, S. R., Herbert, M. A., Cohen, J. A., Casa, T. M., \& Firmender, J. M. (2017). Mathematics Coursetaking and Achievement at the End of High School: Evidence From the Education Longitudinal Study of 2002. Journal of Writing Research, 2002, 165.

Diana. (2017). Pemanfaatan Ict Dalam Pembelajaran Matematika Bagi Anak Usia Dini. Edukasi, 2(1). https://doi.org/10.18592/jea.v1i1.1534

Eminita, V., \& Astriyani, A. (2018). Persepsi Orang Tua Terhadap Kecerdasan Majemuk Anak. FIBONACCI: Jurnal Pendidikan Matematika Dan Matematika, 4(1), 1. https:// doi.org/10.24853/fbc.4.1.1-16

Fauziddin. (2016). Peningkatan Kemampuan Matematika Anak Usia Dini Melalui Permainan Jam Pintar Di Taman Kanak - Kanak Pembina Kec. Bangkinang Kota. Jurnal Paud Tambusai, 2(1), 55-62. https:// doi.org/10.31004/obsesi.v1i1.32

Giganti, P. (2001). Math at Home: Helping your Children Learn and Enjoy Mathematics. Sonoma County Office of Education, California Math Project: North Coast, and California Mathematics Council.

Irma, C. N., Nisa, K., \& Sururiyah, S. K. (2019). Keterlibatan Orang Tua dalam Pendidikan Anak Usia Dini di TK Masyithoh 1 Purworejo. Jurnal Obsesi : Jurnal Pendidikan Anak Usia Dini, 3(1), 214. https://doi.org/10.31004/obsesi.v3i1.152

Ismawati. (2020). Cara Seru Memperkenalkan Matematika Pada Anak. Ibu Pedia. https://www.ibupedia.com/artikel/balita/cara-seru-memperkenalkan-matematikapada-anak

Karnawati, K., \& Mardiharto, M. (2020). Sekolah Minggu Masa Pandemi Covid 19: Kendala, Solusi, Proyeksi. Didache: Journal of Christian Education, 1(1), 13. https://doi.org/10.46445/djce.v1i1.291

Kemdikbud. (2015). Pedoman Pengelolaan Pembelajaran PAUD (Issue 021).

Kemdikbud, D. P. (2020). Bermain Matematika Yang Menyenangkan Dengan Anak Dirumah. Kementerian Pendidikan Dan Kebudayaan Republik Indonesia, 1-26.

Kerkhof, N. (2017). Mom, Dad, Help Please: The Home Environment' s Influences on a Child's Math Ability. http://scholarship.claremont.edu/cmc theses/1664

Kim, J. (2015). The Development and Validation of a Scale to Measure the Mathematical Interaction of Young Children's Parents. Korean Journal of Child Studies, 36(5), 95-113. https:// doi.org/10.5723/KJCS.2015.36.5.95

Lestari KW. (2011). Konsep Matematika Untuk Anak Usia Dini. In Seri Bacaan Orang Tua. Jakarta: Direktorat Jenderal Pendidikan Anak Usia Dini Nonformal dan Informal Kementerian Pendidikan Nasional \& Anak Usia Din.

Mirawati. (2017). Matematika Kreatif: Pembelajaran Matematika bagi Anak Usia Dini Melalui Kegiatan yang Menyenangkan dan Bermakna. Jurnal Anak Usia Dini Dan Pendidikan Anak Usia Dini, 3(3), 227-239. https:// doi.org/10.17509/cd.v3i2.10333

Murdiani. (2018). Meningkatkan Motivasi Dan Hasil Belajar Menjumlahkan Pecahan Melalui Model Pembelajaran Kooperatif Tipe Make A Match Siswa Kelas IV SDN Hariang Kecamatan Banua Lawas Kabupaten Tabalong. Sagacious Jurnal Ilmiah Pendidikan Dan Sosial, 4(2), 35-40. 
Musrikah. (2017). Pengajaran Matematika Pada Anak Usia Dini. Martabat: Jurnal Perempuan Dan Anak, 1(154-174). https://doi.org/10.21274/martabat.2017.1.1.153-174

Novikasari, I. (2016). Matematika dalam Program Pendidikan Anak Usia Dini (PAUD). Bunayya: Jurnal Pendidikan Anak, 2(1), 1-16. https:// doi.org/10.38153/alm.v1i2.9

Obiakor, T., Andeniaran, A., \& Obiakor, T., \& Adeniran, A. (2020). COVID19: Impending Situation Threatens to Deepen Nigerias Education. Center For The Study Of The Economies Of Africa, 1-7.

Oktavianingsih, E. (2019). Pengembangan Program Pelibatan Orangtua dalam Penyelenggaraan Pendidikan Anak Usia Dini. Journal of Early Childhood Care and Education, 1(2), 1. https:// doi.org/10.26555/jecce.v1i2.231

Purwanto, A., Pramono, R., Asbari, M., Santoso, P. B., Wijayanti, L. M., Hyun, C. C., \& Putri, R. S. (2017). Studi Eksploratif Dampak Pandemi COVID-19 Terhadap Proses Pembelajaran Online di Sekolah Dasar. EduPsyCouns: Journal of Education, Psychology and Counseling, 2(1), 165-170.

Ramadan, D. (2019). Kecemasan Siswa Dalam Belajar Matematika. ResearchGate, May. https://www.researchgate.net/publication/333076983_Kecemasan_Siswa_Dalam_Be lajar_Matematika

Ramdhani, A., Ramdhani, M., \& Amin, A. (2014). Writing a Literature Review Research Paper: A step-by-step approach. International Journal of Basic and Applied Science, 3(01), 4756.

Sa, N., \& Kurniawati, T. (2020). Introduction of early childhood mathematics through online learning (e-learning) during the covid-19 pandemic period. Proceeding Umsurabaya, 272-280. http://journal.um-surabaya.ac.id/index.php/Pro/article/view/5987

Siregar \& Restati. (2017). Persepsi Siswa Pada Pelajaran Matematika: Studi Pendahuluan Pada Siswa yang Menyenangi Game. Prosiding Temu Ilmiah X Ikatan Psikologi Perkembangan Indonesia, 224-232.

Utami, F. (2020). Pembelajaran Matematika Anak usia Dini. Gramedia Communication.

Wardhani, D. K. (2017). Peran Guru Dalam Menerapkan Pembelajaran Matematika Yang Menyenangkan Bagi Anak Usia Dini. Jurnal Paud Agapedia, 1(2), 153-159. https:// doi.org/10.17509/jpa.v1i2.9355

Wardhani, T. Z. Y., \& Krisnani, H. (2020). Optimalisasi Peran Pengawasan Orang Tua Dalam Pelaksanaan Sekolah Online Di Masa Pandemi Covid-19. Prosiding Penelitian Dan Pengabdian Kepada Masyarakat, 7(1), 48. https://doi.org/10.24198/jppm.v7i1.28256

Wargadinata, W., Maimunah, I., Dewi, E., \& Rofiq, Z. (2020). Student's Responses on Learning in the Early COVID-19 Pandemic. Tadris: Jurnal Keguruan Dan Ilmu Tarbiyah, 5(1), 141-153. https://doi.org/10.24042/tadris.v5i1.6153

Yilmaz, Z. (2017). Young children's number sense development: Age related complexity across cases of three children. International Electronic Journal of Elementary Education, 9(4), 891-902. 